Intersections

Canadian Journal of Music

Revue canadienne de musique
Intersections CANADIAN JOURAL OF MUSIC

\title{
Two-Part Transition or Two-Part Subordinate Theme?
}

\section{Carl Wiens}

Volume 31, numéro 1, 2010

Contemplating Caplin

URI : https://id.erudit.org/iderudit/1009284ar

DOI : https://doi.org/10.7202/1009284ar

Aller au sommaire du numéro

Éditeur(s)

Canadian University Music Society / Société de musique des universités canadiennes

ISSN

1911-0146 (imprimé)

1918-512X (numérique)

Découvrir la revue

Citer cet article

Wiens, C. (2010). Two-Part Transition or Two-Part Subordinate Theme? Intersections, 31(1), 46-65. https://doi.org/10.7202/1009284ar

\section{Résumé de l'article}

Dans l'ouvrage Classical Form de William Caplin (1998), la conclusion d'une transition en deux parties de l'exposition d'une structure sonate et la cadence interne d'un thème subordonné en deux parties partagent le même objectif harmonique : la dominante de la nouvelle clef. Dans cet article, l'auteur affirme que le choix entre les deux n'est pas aussi net que le suggère Caplin en faisant valoir que la fonction de ces passages doit être lue dans le contexte de la sonate entière, plutôt qu'à travers des interprétations analytiques plus limitées des mouvements de la sonate pris isolément. Deux oeuvres de Beethoven sont étudiées : le premier mouvement de la Sonate pour piano, opus $2, n^{\circ} 3$, et le premier mouvement de la Sonate pour piano, opus $10, \mathrm{n}^{\circ} 2$.
All Rights Reserved (C Canadian University Music Society / Société de musique des universités canadiennes, 2012
Ce document est protégé par la loi sur le droit d'auteur. L’utilisation des services d'Érudit (y compris la reproduction) est assujettie à sa politique d'utilisation que vous pouvez consulter en ligne.

https://apropos.erudit.org/fr/usagers/politique-dutilisation/ 


\title{
TWO-PART TRANSITION OR TWO-PART SUBORDINATE THEME?
}

\author{
Carl Wiens
}

William Caplin's Classical Form (1998) offers music theorists a methodology built around clear definitions and examples of the various components of classical formal design. Caplin's approach emphasizes the central role played by harmony and its requisite schema in articulating classical form, most notably sonata form. Melody and motive also play important roles, but in Caplin's method they take their lead from the underlying harmonic scheme. What results are strict formal categories that can be used for comparison, thus allowing the listener to observe how closely a musical passage adheres to or diverges from the model.

Caplin begins each chapter of his treatise with succinct definitions, followed by a series of musical examples that become progressively more involved. While the lessons of Classical Form can be quickly integrated and applied, confusion often results (as it should!) when considering more complex musical events. For example, the ending of a sonata-form exposition's two-part transition and a two-part subordinate theme's internal cadence share the same harmonic goal-the new key's dominant. So how do we tell them apart?

In the two-part transition, "the first part of the transition leads to a half cadence (or dominant arrival) in the home key, just as in a single non-modulating transition; the second part then modulates to the subordinate key (Caplin $1998,135)$.

By comparison, in the two-part subordinate theme, "sometimes, however, the transition does not modulate and closes instead on the dominant of the home key ... In such cases, the absence of an emphasized subordinate-key dominant at the end of the transition is often rectified by an internal half cadence within the subordinate theme" (Caplin 1998, 115).

While these descriptions are neatly supported with examples, the choice between two-part transition and two-part subordinate theme is not clear. I contend that Haydn, Mozart, and Beethoven often exploited precisely the ambiguity that Caplin highlights. To this end, I discuss two works-the first movement of Beethoven's Piano Sonata op. 2, no. 3, and the first movement of his Piano Sonata op. 10, no. 2-and use Caplin's form-functional approach as the analytical methodology to examine these works and frame my argument.

First, some preliminaries. In figures 1 and 2, I provide summaries of the most frequently occurring transition and subordinate theme types. Transitions typically occur in two varieties: non-modulating and modulating. The harmonic goal of the transition in both cases is a dominant, either the dominant of the 
Non-Modulating Transition (Caplin 1998, 127)

HK: I

$$
\mathrm{IV}-\mathrm{V}
$$

$\mathrm{HC}$

Modulating Transition (Caplin 1998, 127)

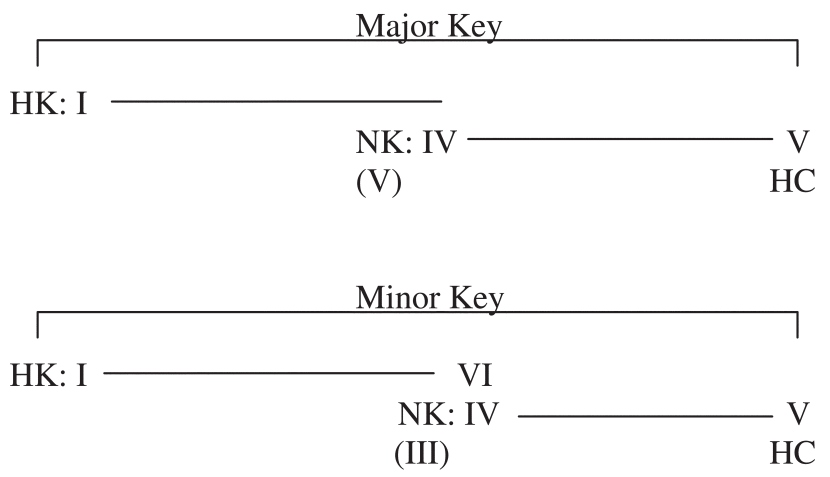

Two-Part Transition (Caplin 1998, 135-37)

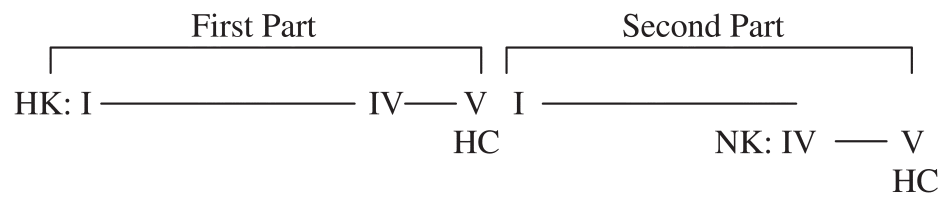

Figure 1. Transition schemata (Exposition), showing modulation from the home key (HK) to the new key (NK), and half cadence closure (HC)

home key (in the non-modulating one) or the dominant of the new key (in the modulating one). The concluding dominant may be articulated either as a dominant arrival or as a half cadence. In the non-modulating transition, the concluding home key's dominant is immediately re-contextualized as the new key's tonic from the moment the subordinate theme begins (e.g., the first movement of Beethoven's Piano Sonata op. 49, no. 2). With the modulating transition, the new key is reached through a pivot chord in the midst of the transition (e.g., the first movement of Beethoven's Piano Sonata op. 49, no. 1). Thus, the modulating transition's goal dominant anticipates the new key's tonic, which typically begins the subordinate theme. A third type of transition features the dominants of both the home key and the new key, as shown in figure 1. Here, the transition divides into two parts, with the first part concluding with the 
Subordinate Theme (Caplin 1998, 97)

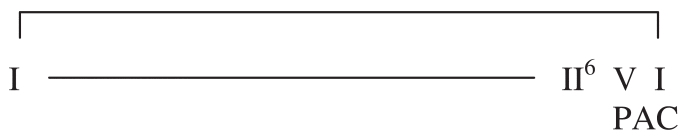

Subordinate Theme Group (Caplin 1998, 121)

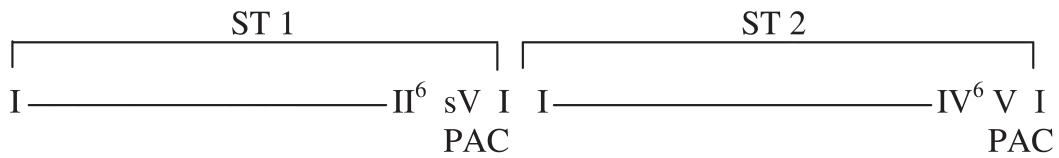

Two-Part Subordinate Theme (Caplin 1998, 115-17)

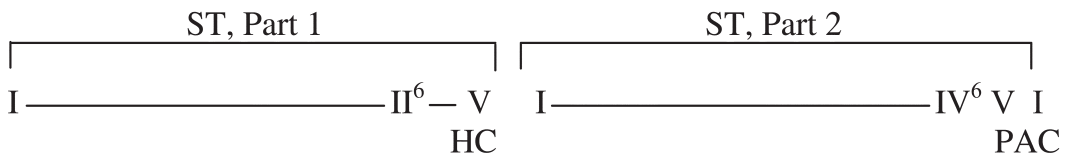

Figure 2. Subordinate theme types (Exposition)

home key's dominant, while the second part ends with the new key's dominant. I will return to this third transition type in a moment.

Music theorists are well acquainted with the ways in which the subordinate theme participates in one of sonata form's central dramas. Its closing perfect authentic cadence confirms the second key area in the exposition and the home key in the recapitulation. Relative to the main theme, the subordinate theme is more loosely structured. It often comprises the three sentential functions: presentation, continuation, and cadential. The sentence lends itself well to a more loosely structured thematic area as a result of its immediate internal repetitions in the presentation phrase and the fragmentation of the standard twomeasure basic idea in the continuation phrase. Figure 2 provides a harmonic summary of three of the most frequently found subordinate theme designs. With the first, a single thematic unit comprises the entire subordinate theme, complete with the concluding perfect authentic cadence. In these cases, any of the three intrathematic functions (initiating, medial, or concluding) may be expanded to take in more than the standard eight-measure theme. With the second, instead of a single subordinate theme we find two subordinate themes, each one complete with its own theme type (sentence, period, etc.) and its own perfect authentic cadence. To some extent, either one of the two subordinate 
Two-Part Transition

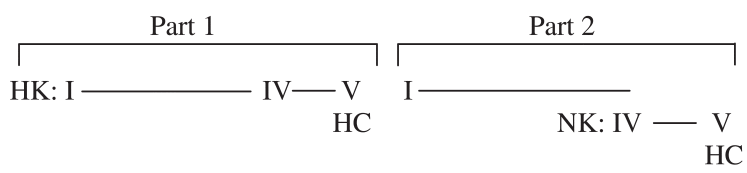

Two-Part Subordinate Theme

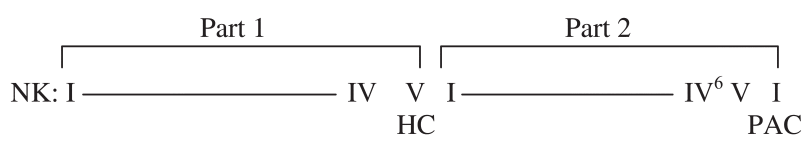

Figure 3. Two-part transition and two-part subordinate theme intermingled (Exposition)

themes can be heard as extraneous to the subordinate theme function, the result being a more loosely structured section.

With the two-part subordinate theme-the third diagram in figure 2-a half cadence replaces the first perfect authentic cadence, while the second perfect authentic cadence occurs as expected. The result is a subordinate theme that comprises a large two-part antecedent-consequent structure (rather than two distinct subordinate themes with perfect authentic cadences), with the first part serving as the antecedent (articulated by the expected half cadence) and the second part serving as the consequent (ending with a perfect authentic cadence).

To highlight the shared harmonic goal of the two-part transition's second part and the two-part subordinate theme's first part, the two are juxtaposed in figure 3. From this figure, we can see where the problem lies. Since these two are almost harmonically indistinguishable, how can we tell which is the transition and which is the subordinate theme? Is the passage in question based on a tight-knit theme? What can the recapitulation tell us about our experience with the exposition? To answer these questions, let us consider two pieces: the first movements of Beethoven's Piano Sonatas op. 2, no. 3 and op. 10, no. 2. To illustrate my points, I have annotated the relevant passages from these works in examples 1-4 using Caplin's methodology and practices.

The first movement of Beethoven's Piano Sonata op. 2, no. 3, opens with a thirteen-measure main theme, a sentence with a repeated continuation, as shown in example 1. It closes on the downbeat of $\mathrm{m}$. 13 with a perfect authentic cadence. The transition follows with new contrasting material, reaching its harmonic goal, the home key's dominant, with a half cadence in m. 21. Six measures of standing-on-the-dominant ensue. Beethoven follows the transition with what sounds like a subordinate theme covering $\mathrm{mm}$. 27-46. This passage is structured as a period: $\mathrm{mm} .27-33$, the antecedent, and mm. 34-46, the consequent. However a couple of things are atypical. Rather than beginning in the expected key of G major, the home key's dominant, this passage begins in 
$\mathrm{G}$ minor. Although $\mathrm{G}$ is the tonic, a modal shift at this point in the exposition is surprising. It closes with a half cadence in $\mathrm{G}$ minor at $\mathrm{m}$. 43, followed by four measures of standing-on-the-dominant-an ending that is similar to the conclusion of a modulating transition. Musical material similar to that heard in mm. 24-26 (the descending sixteenth-note scalar passages) returns to conclude this passage in mm. 39-45, further supporting a reading of this passage as the second part of the movement's transition. Another theme, a compound period, follows the dominant prolongation, now in the expected G major. It
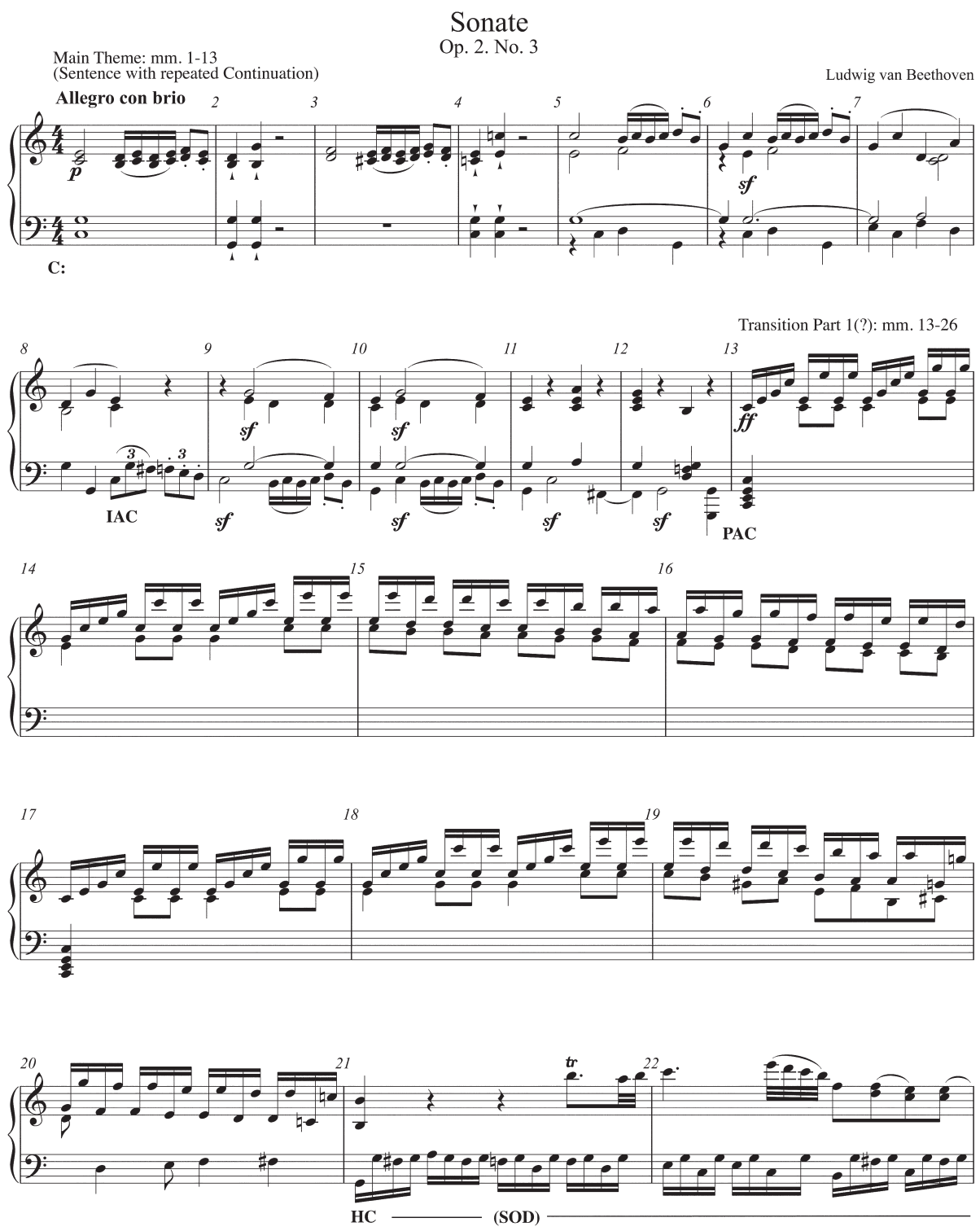

Example 1. Beethoven, Piano Sonata op. 2, no. 3, first movement (Exposition) (1 of 4 ) 


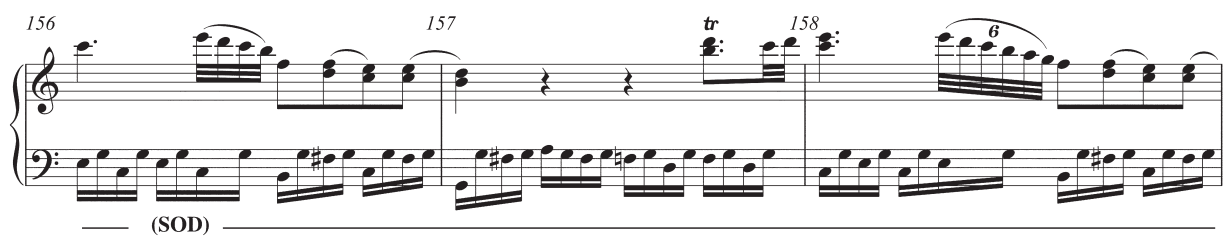

Transitiion Part 2 or

Subordinate Theme Part 1: mm. 161-180

(Period: Antecedent mm. 161-167; Consequent mm. 168-180)
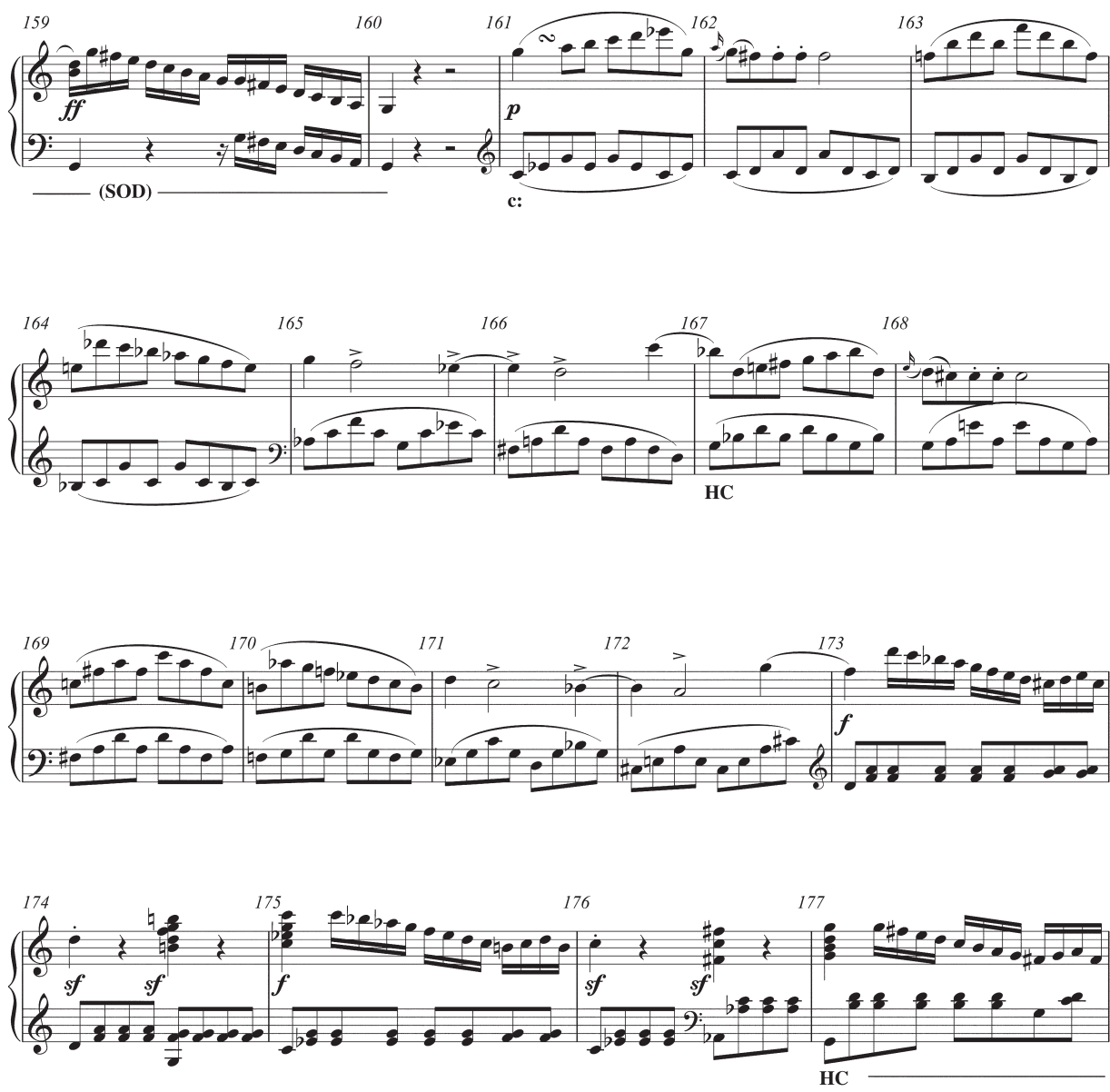

Example 1. Beethoven, Piano Sonata op. 2, no. 3, first movement (Exposition) (2 of 4) 
Subordinate Theme Part 2: mm. 181-211

(Compound Period: Antecedent (Sentence) mm. 181-188;
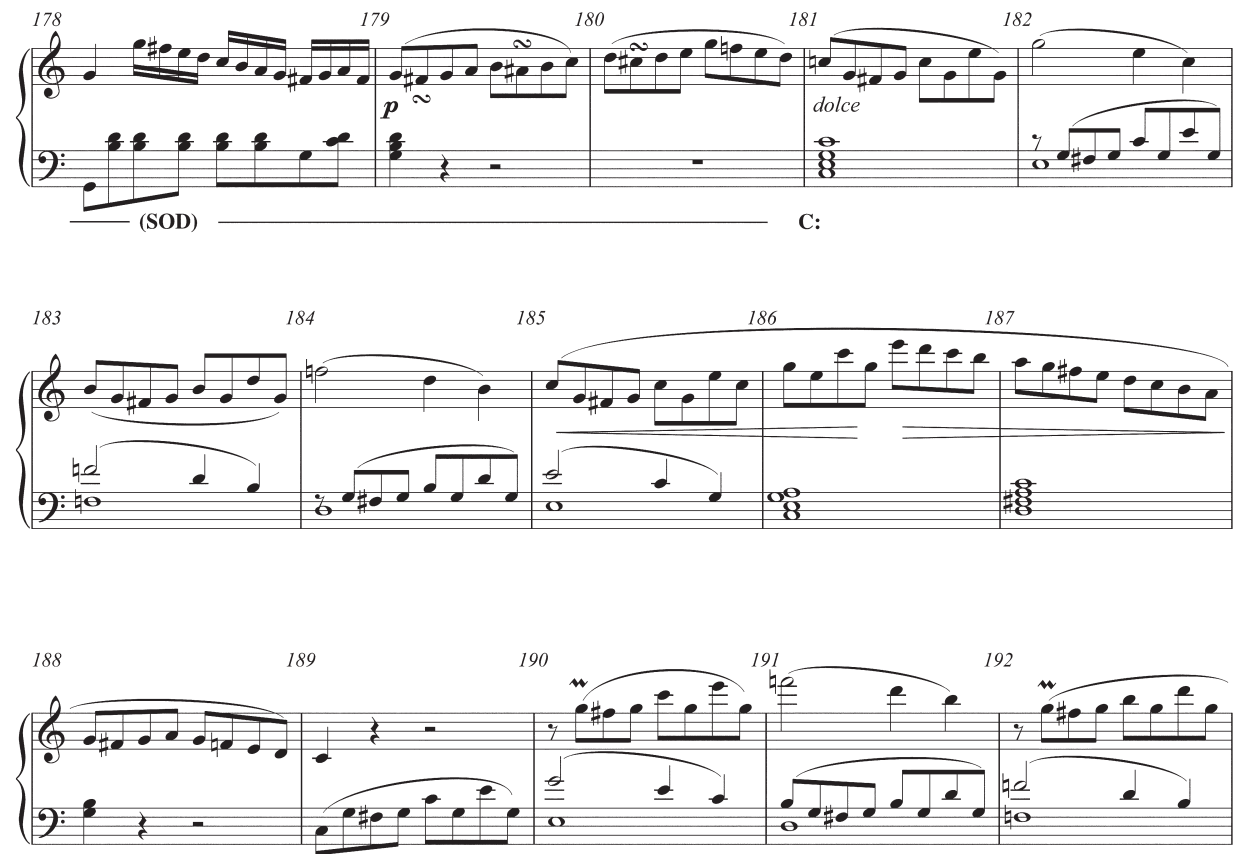

G: PAC
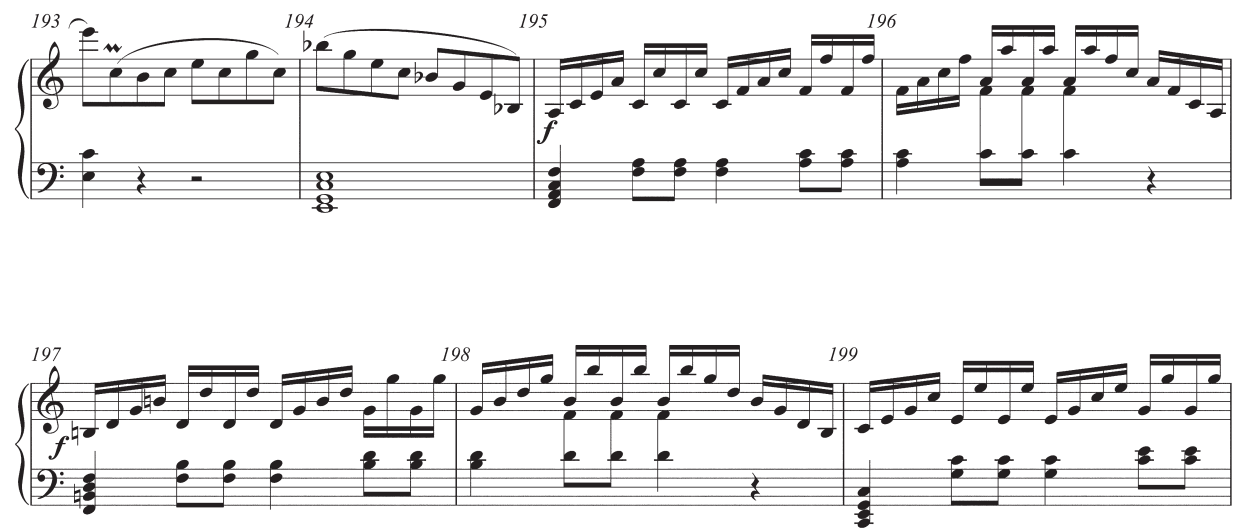

Example 1. Beethoven, Piano Sonata op. 2, no. 3, first movement (Exposition) (3 of 4) 

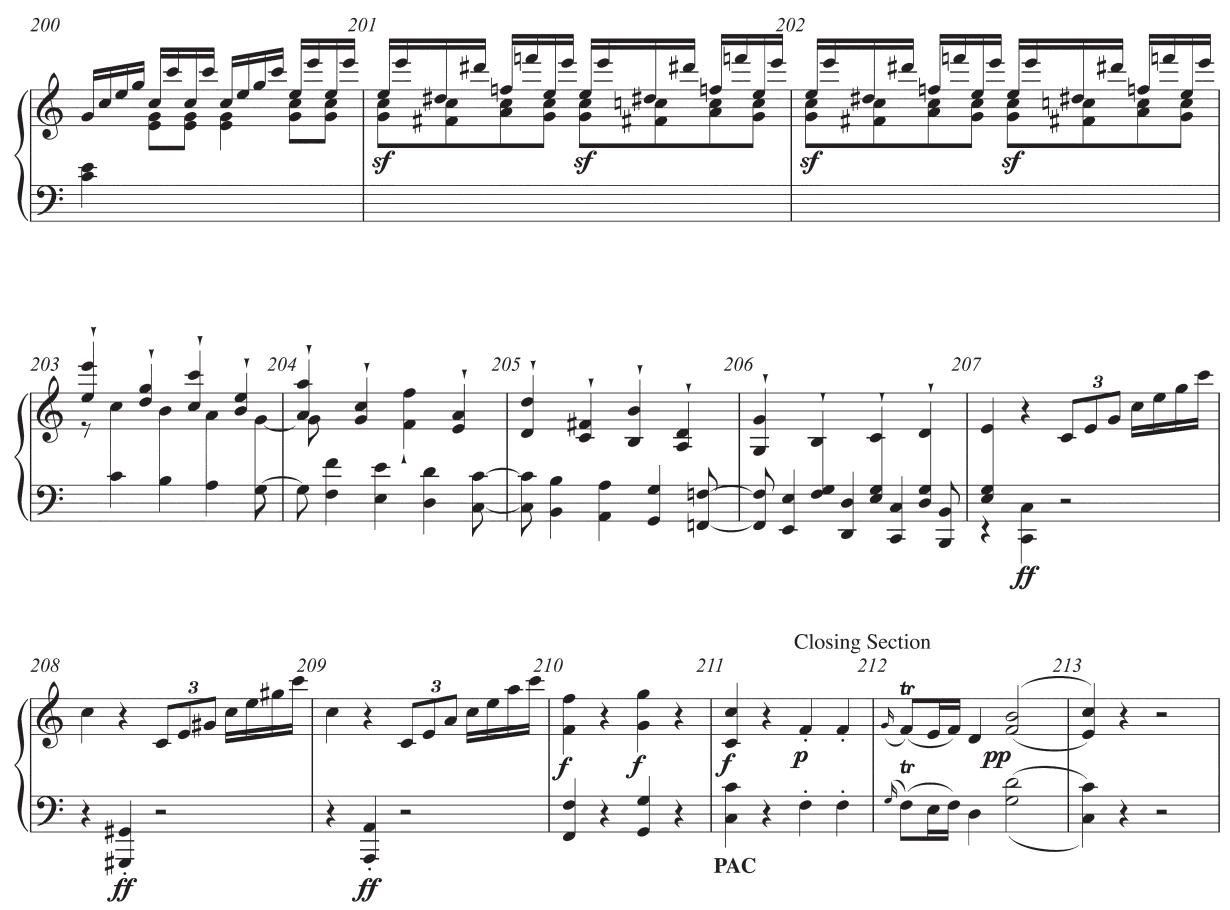

Example 1. Beethoven, Piano Sonata op. 2, no. 3, first movement (Exposition) (4 of 4)

sounds more like the movement's actual subordinate theme, as it is in the expected key and mode as well as closing with the expected perfect authentic cadence in $\mathrm{m} .77 .^{1}$

In the movement's recapitulation, Beethoven returns the exposition's transition, albeit with some modifications, as shown in example 2. Nonetheless, the home key's dominant remains its goal, arriving in $\mathrm{m}$. 155. As in its exposition counterpart, the transition's concluding dominant is followed by six measures of standing-on-the-dominant. The minore theme, now in $\mathrm{C}$ minor, follows the transition. The ambiguity of the exposition, whether this minore passage is the first part of a two-part subordinate theme (ending with the requisite internal half cadence) or the second part of a two-part transition, is not as pronounced in the recapitulation because we have heard the minore passage before. We expect it. From the standpoint of transition, the concluding dominant of this minore passage is redundant, the music having reached the home key's dominant-the goal of the recapitulation-at the conclusion of the preceding passage. Consequently, I hear the recapitulation's minore passage as the first part of a two-part subordinate theme rather than the second part of a two-part transition. This perspective, in turn, colours how I hear the exposition, but

1 James Hepokoski and Warren Darcy use this movement as an example of their trimodular block (TMB). See Hepokoski and Darcy (2006, 172-75). 

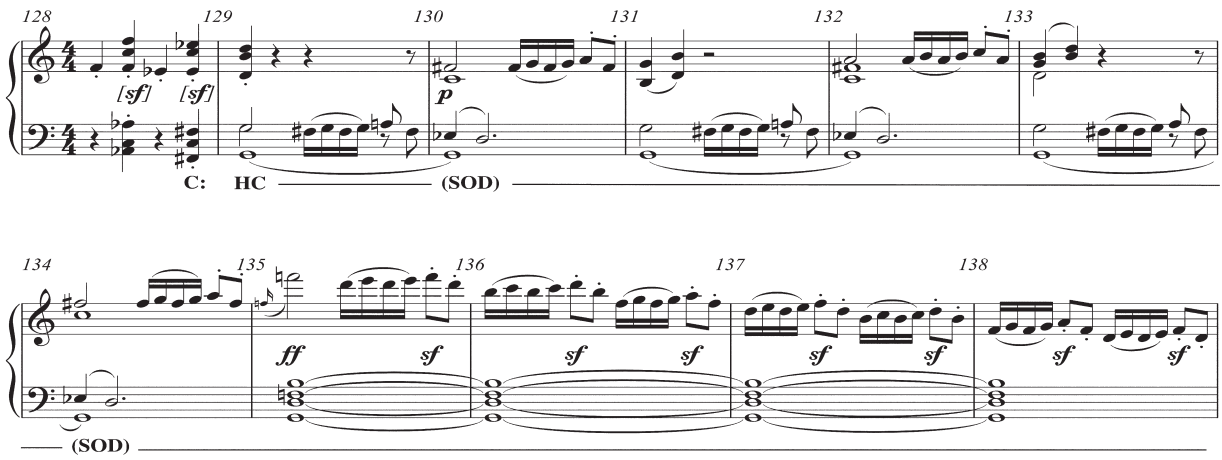

Main Theme: mm. 139-146
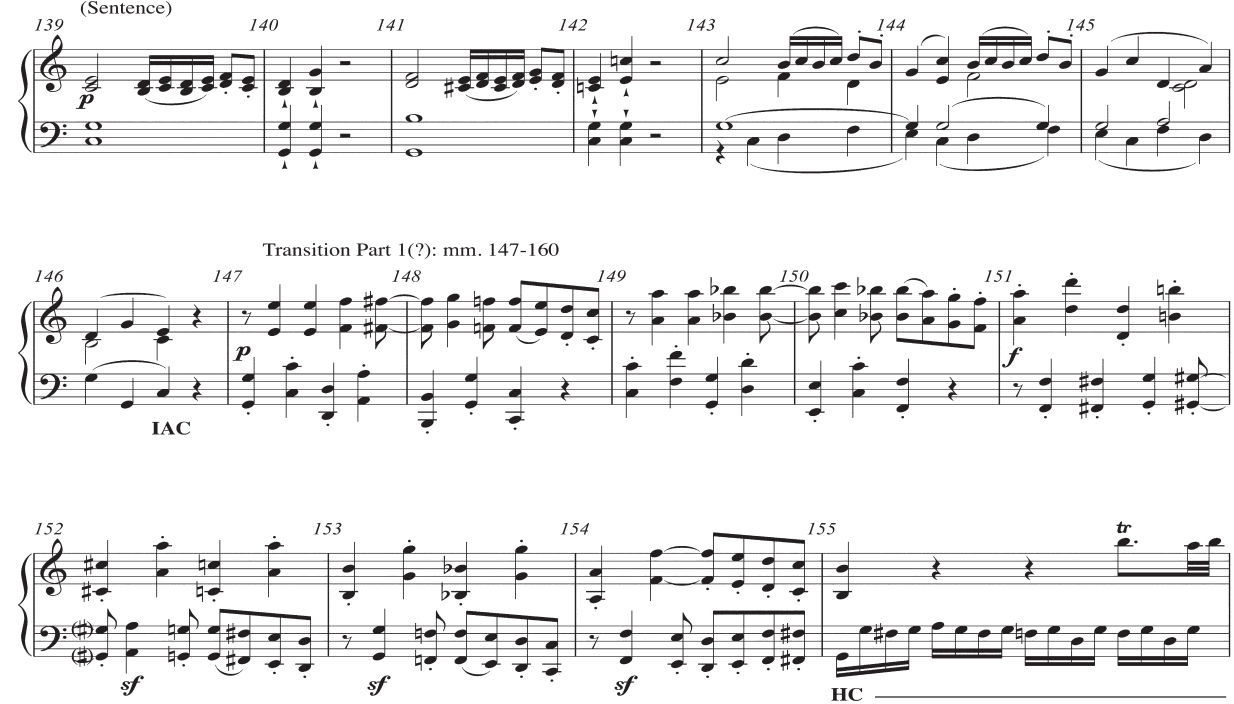

Example 2: Beethoven, Piano Sonata op. 2, no. 3, first movement (Development's dominant arrival and Recapitulation) (1 of 4 ) 


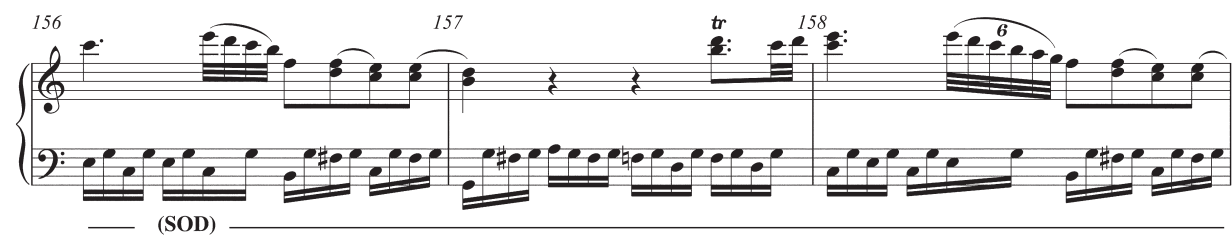

Transitiion Part 2 or

Subordinate Theme Part 1: mm. 161-180

(Period: Antecedent mm. 161-167; Consequent mm. 168-180)
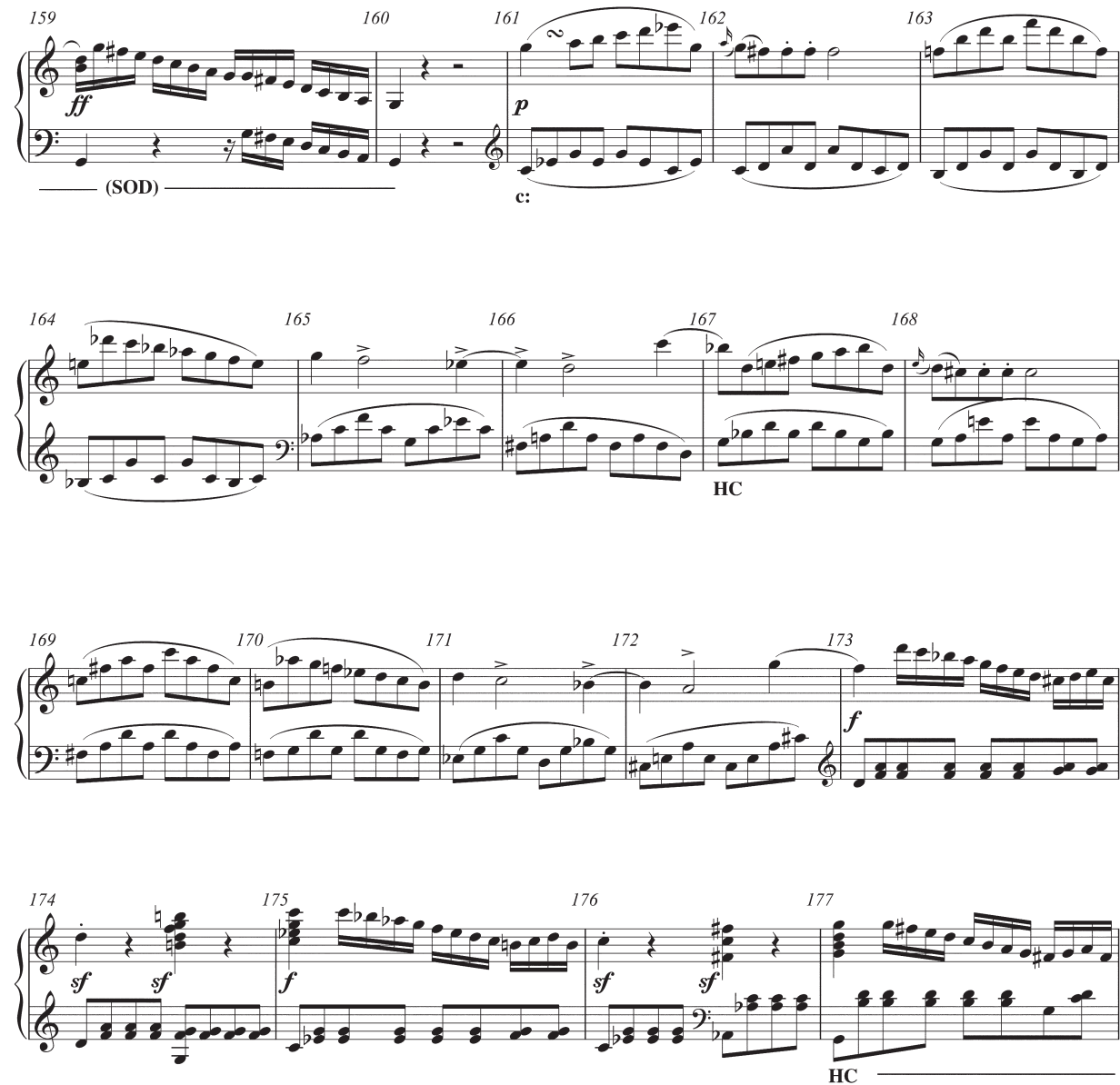

Example 2: Beethoven, Piano Sonata op. 2, no. 3, first movement (Development's dominant arrival and Recapitulation) (2 of 4) 

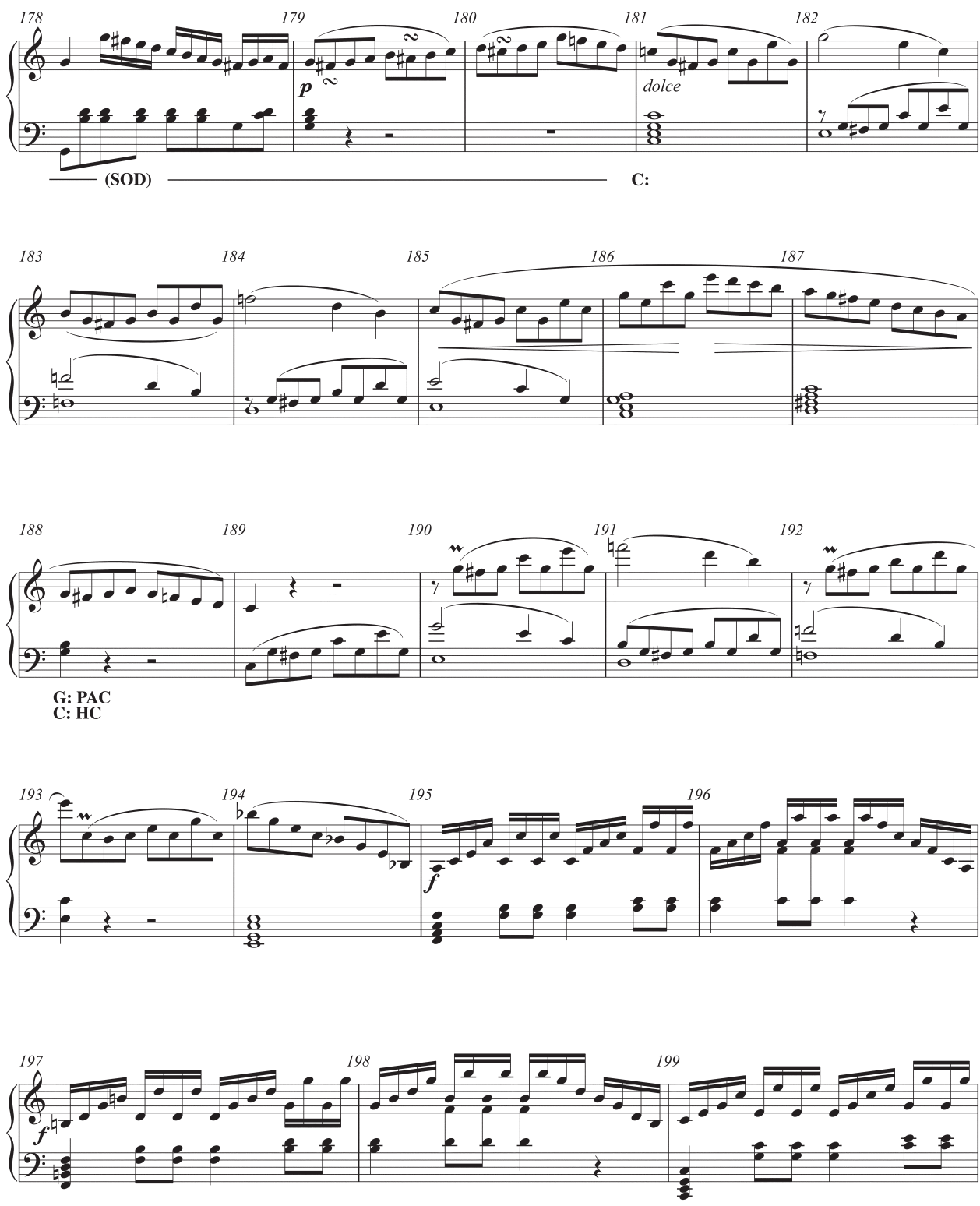

Example 2: Beethoven, Piano Sonata op. 2, no. 3, first movement (Development's dominant arrival and Recapitulation) ( 3 of 4 ) 

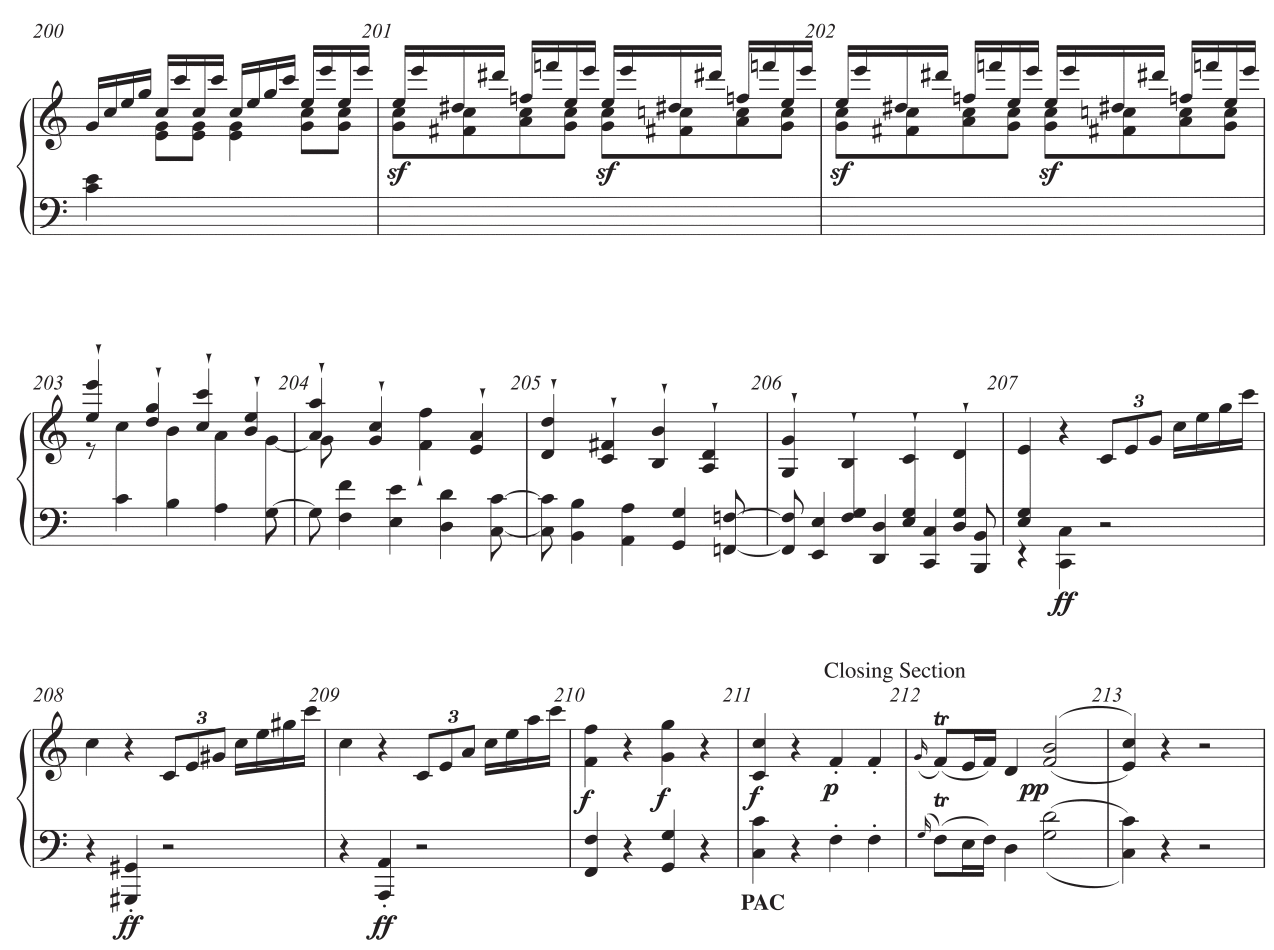

Example 2: Beethoven, Piano Sonata op. 2, no. 3, first movement (Development's dominant arrival and Recapitulation) (4 of 4 )

only in retrospect-after having heard the recapitulation. Nonetheless some doubt remains, since the similar concluding gestures shared by these two passages in the exposition return intact in the recapitulation.

Similar to the previous example, the first movement of Beethoven's Piano Sonata op. 10, no. 2, opens with a main theme built as a sentence, shown in example 3. It closes on the downbeat of $\mathrm{m} .12$ with a perfect authentic cadence in the home key. What appears to be the transition follows in m. 13. As noted by Caplin $(1998,274 n 6)$, this transition is quite short (only six measures long!). It ends on a dominant as expected, but not the dominant of the home key, $\mathrm{F}$ major, nor the dominant of the new key, $\mathrm{C}$ major. Beethoven transforms the home key's tonic triad to a German augmented sixth, which resolves on the dominant of A, the home key's mediant. The music that follows immediately begins in the home key's dominant, C, leading to a half cadence at m. 30, and is followed by eight measures of standing-on-the-dominant. Because of the brevity of the transition, it appears that mm. 19-37 comprise the second part of a two-part transition. These measures conclude with a half cadence in the new key, C major, and are followed by a dominant prolongation, both hallmarks of transition function. However, mm. 19-37 are structured as a hybrid theme (compound basic idea, repeated, plus continuation-cadential), making the case 
Sonate

Op. 10 No. 2

Main Theme: mm. 1-12

(Sentence with expanded continuation)

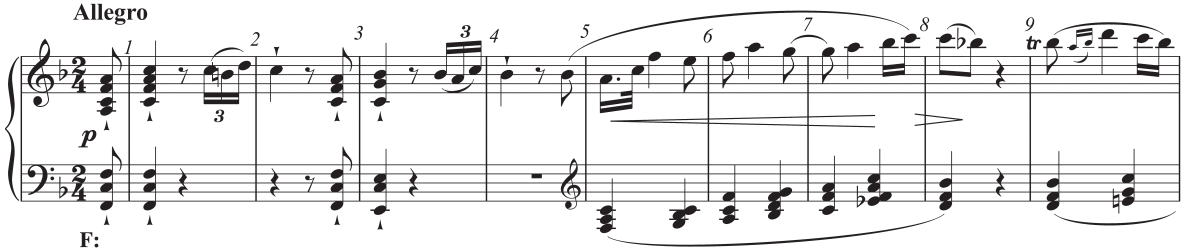

Transition Part 1(?): mm. 13-18

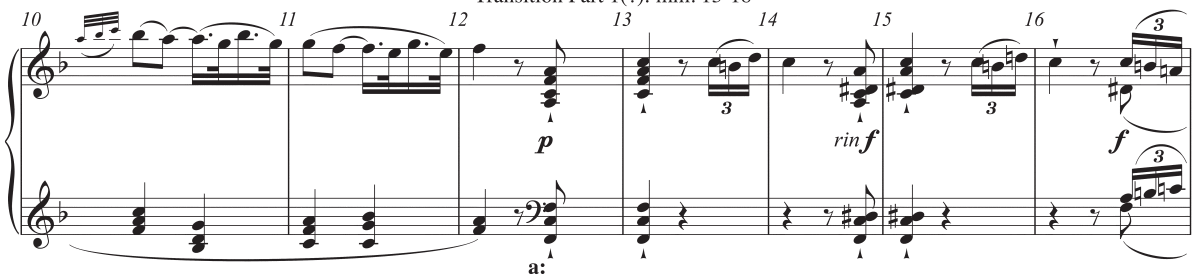

Transition Part 2 or

Subordinate Theme Part 1: mm. 19-37

(Hybrid: Compound Basic Idea (repeated) mm. 19-26;
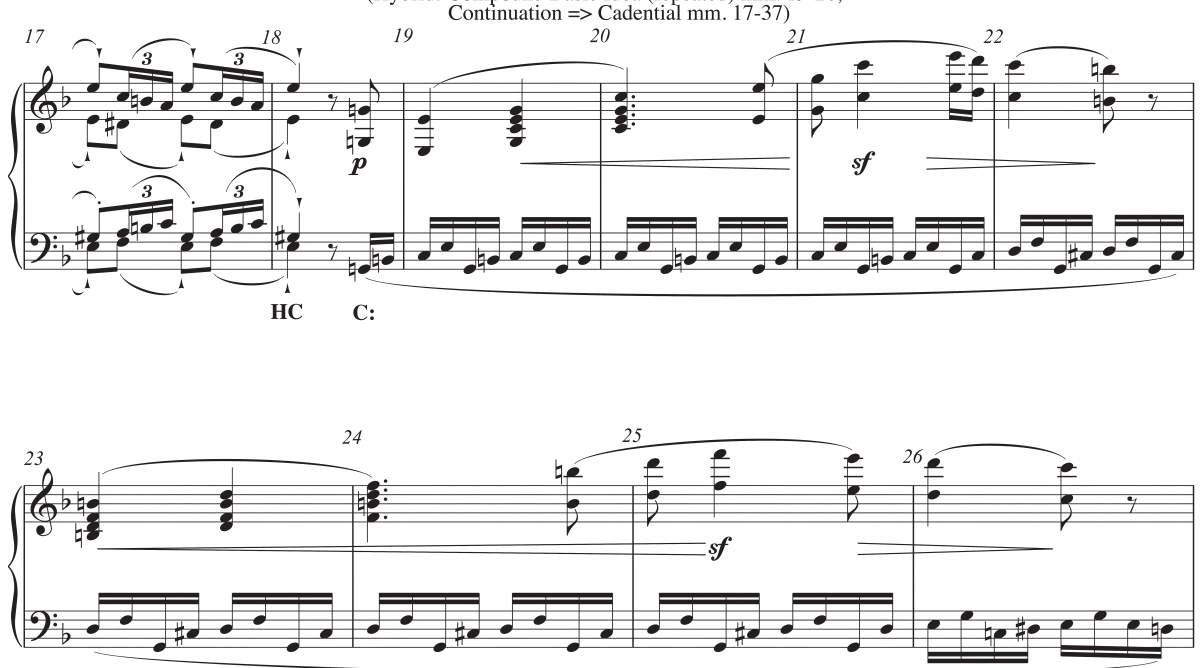

Example 3: Beethoven, Piano Sonata op. 10, no. 2, first movement (Exposition) (1 of 3) 

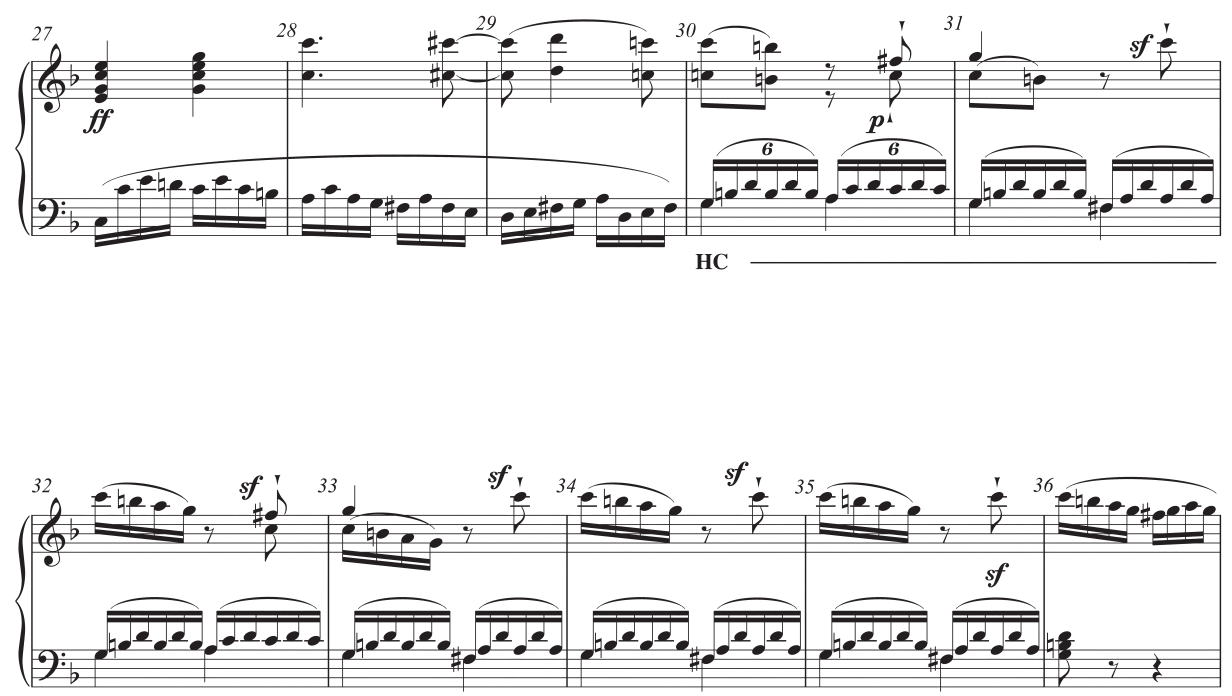

(SOD)
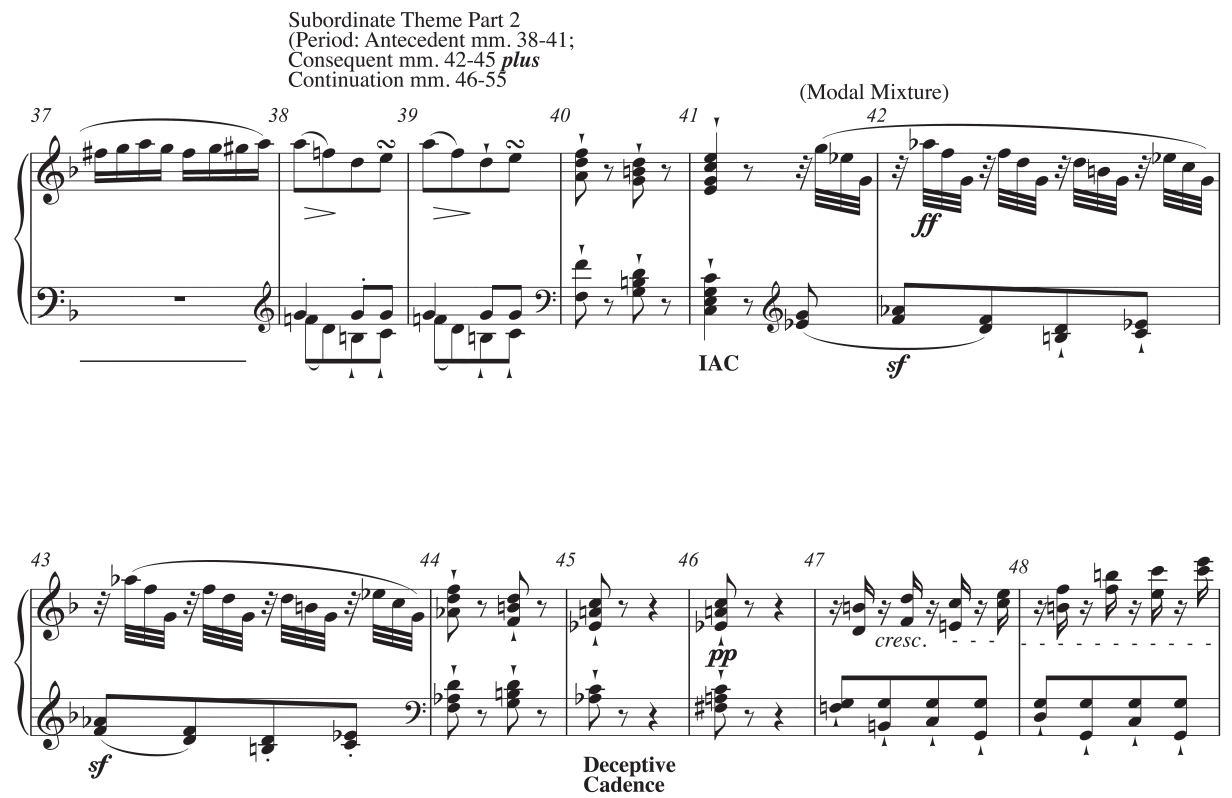

Example 3: Beethoven, Piano Sonata op. 10, no. 2, first movement (Exposition) (2 of 3) 

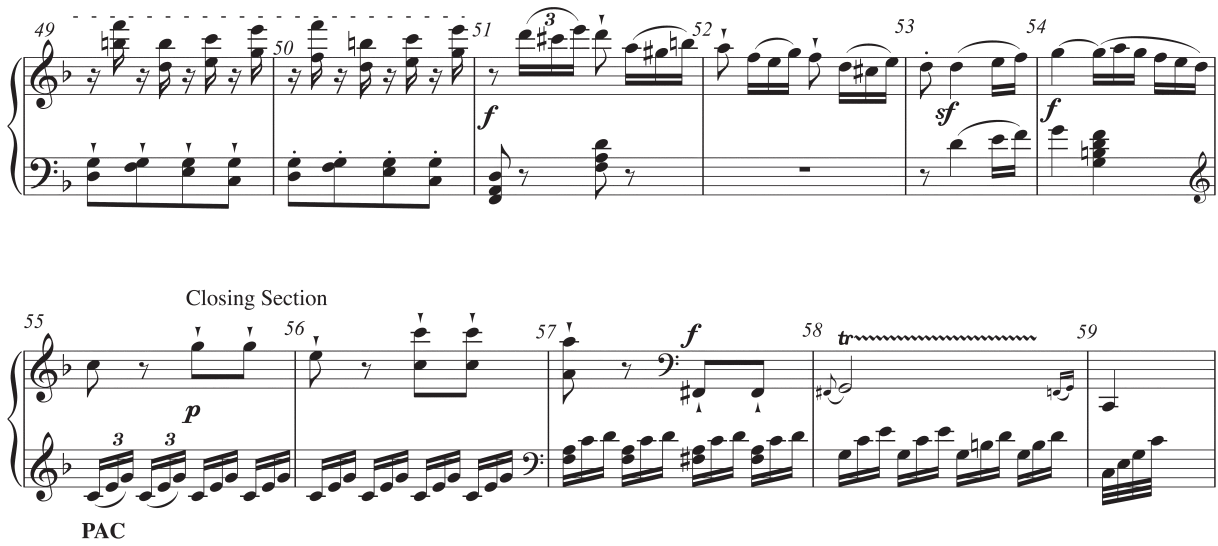

Example 3: Beethoven, Piano Sonata op. 10, no. 2, first movement (Exposition) (3 of 3)

for this passage as the first part of a two-part subordinate theme. Following the dominant prolongation, a new theme unfolds, also in $\mathrm{C}$ major (a period plus continuation), reaching its goal in $\mathrm{m} .59$ with the requisite perfect authentic cadence.

In the recapitulation, Beethoven resolves the question of whether mm. 19-37 is best heard as the second part of a two-part transition, or as the first part of a two-part subordinate theme, as shown in example 4. He omits the repeat of mm. 13-18, the exposition's transition, the passage that ended on the "wrong" dominant. Instead, the repetition of what appeared to be the first part of the exposition's subordinate theme plays the transition's role in the recapitulation. Now in the home key, it concludes with the expected half cadence in m. 162. It is followed by a repetition of the second part of the exposition's subordinate theme, mm. 170-189, also in the home key and, once again, ending with the requisite perfect authentic cadence. ${ }^{2}$

However, the decision to omit the exposition's transition in the recapitulation is not solely a matter of simply "wanting to leave it out." Instead, this choice is better understood after considering how the recapitulation begins. The main theme appears to return in $\mathrm{m}$. 118 following the development's concluding standing-on-the-dominant found in mm. 113-17. However, the main theme returns not in the expected F major, but in D major, the home key's modally inflected submediant. Complicating matters, Beethoven brings back the entire twelve-measure main theme, complete with its concluding perfect authentic cadence, all in D major. Following this cadence, there is a pause in the action. The music resumes following the anacrusis to $\mathrm{m}$. 131, but now D major's tonic is reinterpreted as the dominant of $\mathrm{F}$ major's supertonic. The home key's dominant follows two measures later-the expected harmonic goal of

2 Hepokoski and Darcy $(2006,271-75)$ also discuss this passage. 

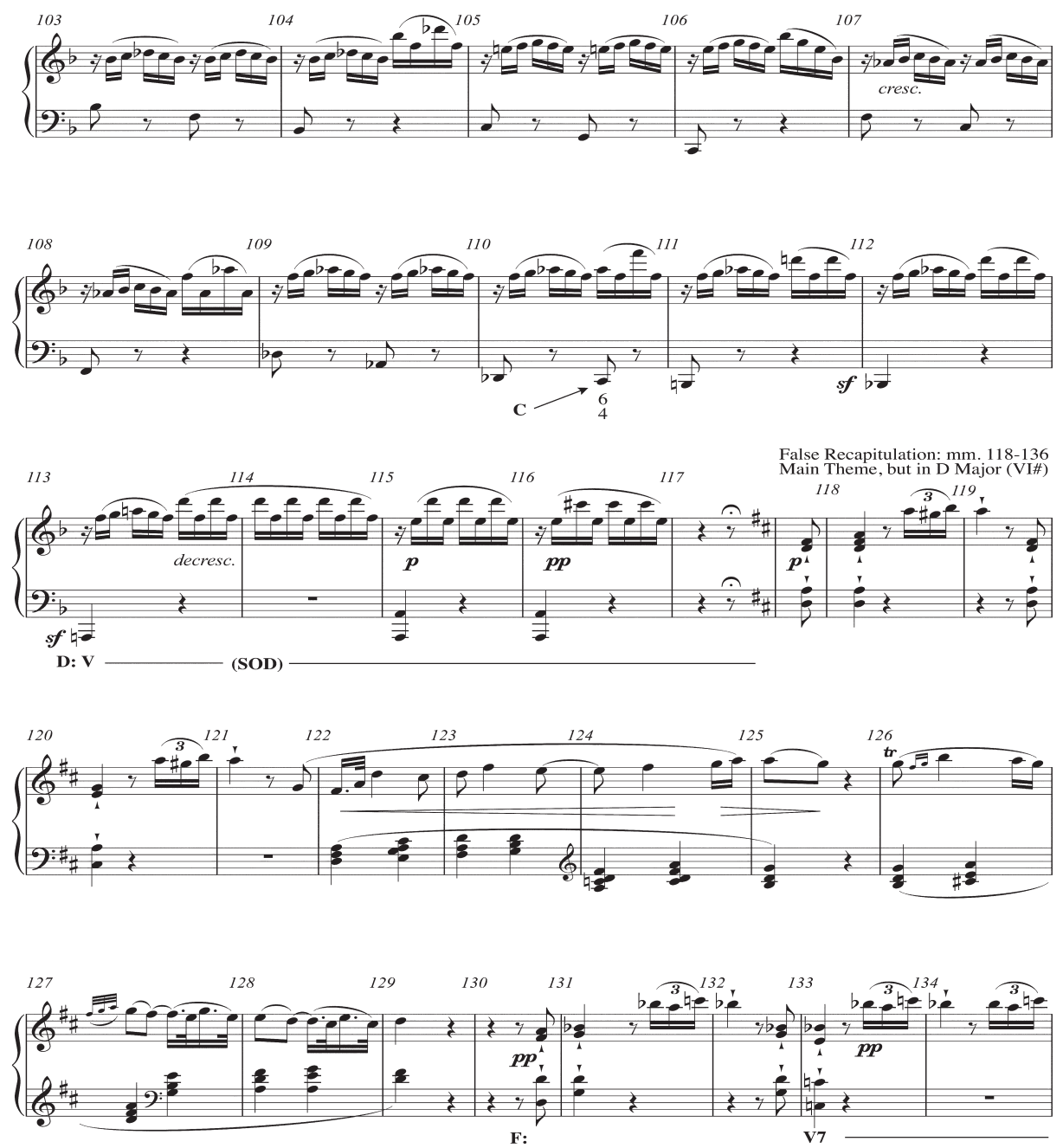

Example 4: Beethoven, Piano Sonata op. 10, no. 2, first movement (Development's dominant arrival and Recapitulation) (1 of 3 ) 


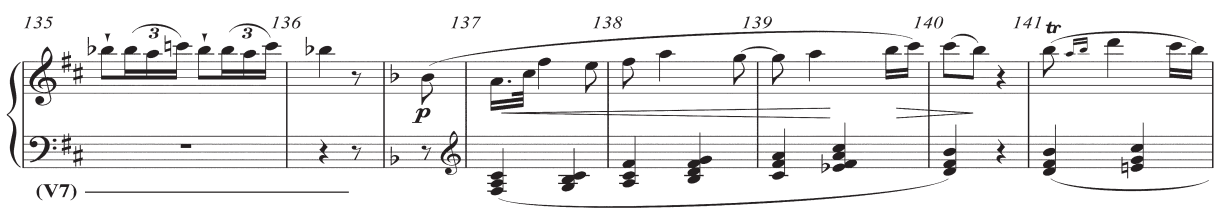

Transition Part 2 or

Subordinate Theme Part 1: mm. 19-37

(Hybrid: Compound Basic Idea (repeated) mm. 145-152;
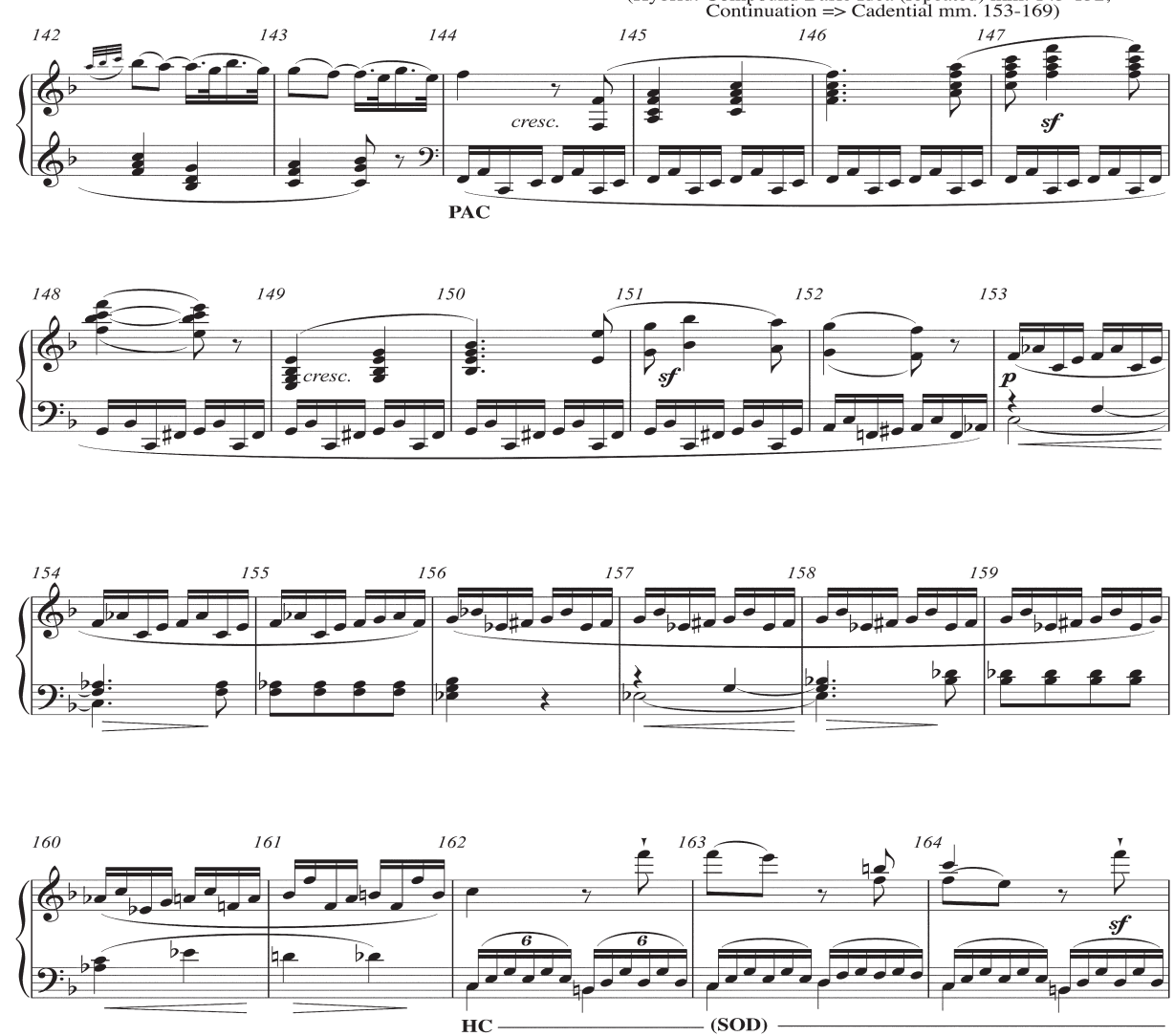

Example 4: Beethoven, Piano Sonata op. 10, no. 2, first movement (Development's dominant arrival and Recapitulation) (2 of 3 ) 


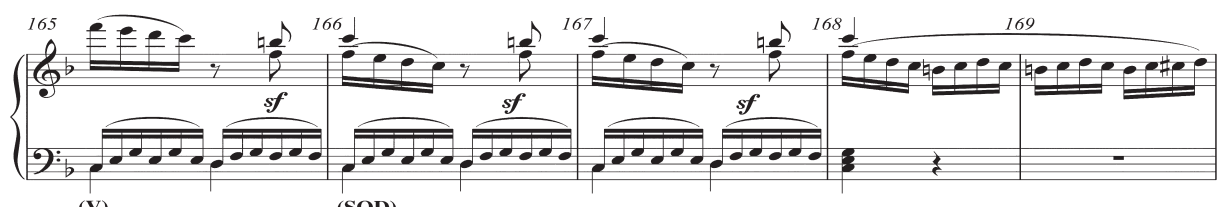

(V)

(SOD)

Subordinate Theme Part 2: mm. 170-187

(Period: Antecedent mm. 170-173;

Consequent $\mathrm{mm}$. 174-177 plus
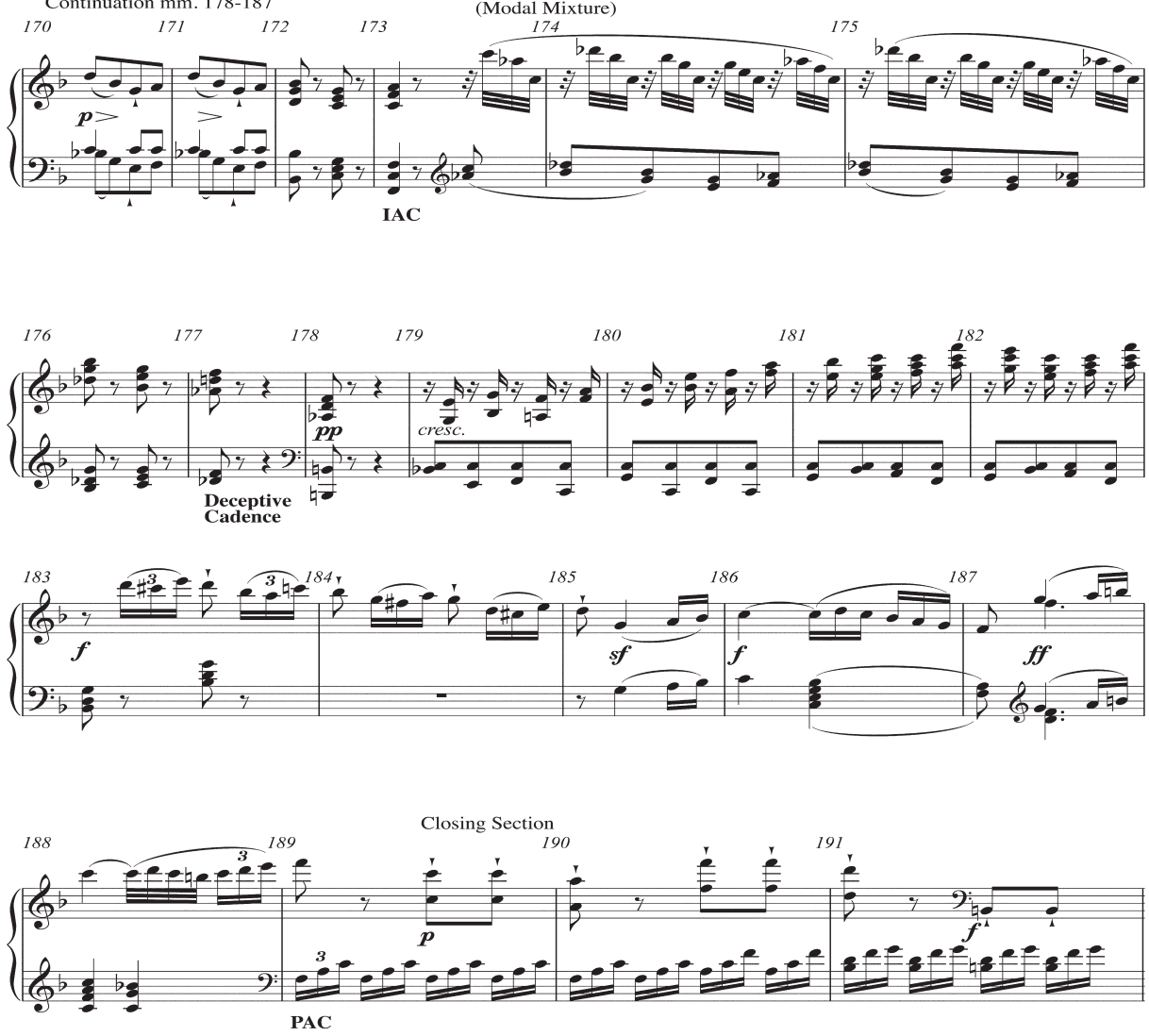

Example 4: Beethoven, Piano Sonata op. 10, no. 2, first movement (Development's dominant arrival and Recapitulation) (3 of 3 ) 
the development. As a result, the return of the main theme in D major is best heard as a false recapitulation that was prepared in the measures leading up to this point in the movement. In $\mathrm{m}$. 110, the music goes past the expected home key's dominant (noted by the arrow in example 4)-the expected harmonic goal of the development-ending instead on D major's dominant in m. 113.

Now that the $\mathrm{D}$ major main theme is understood as being part of the development, mm. 137-44 can be heard as the actual main theme, complete with the concluding perfect authentic cadence, even though it comprises only the exposition's expanded continuation phrase (preceded by a recollection of the basic idea at the end of the development in $\mathrm{mm}$. 130-36). The omission of the exposition's transition, mm. 13-18, does not appear out of place, because of the confusion regarding the recapitulation's main theme. Instead, the exclusion is warranted, as its role in the exposition was one of misdirection, its concluding E major harmony suggesting a move to the home key's mediant, A, rather than the expected home key's dominant, C. I hear mm. 145-69 as the recapitulation's transition, complete with the concluding half cadence in the home key. This reading also suggests that the exposition's transition is actually in two parts, but once again only in retrospect. Furthermore, mm. 13-18 could be heard as a false closing section to the exposition's main theme, albeit an unusual one (Caplin 1998, 129, 131). While this passage does not prolong the home key's tonic, it clearly makes use of the main theme's thematic material, thus linking it to the main theme.

In conclusion, the decision to hear a passage as transition or subordinate theme hinges on our experience with the entire movement, both exposition and recapitulation, rather than one of the sections in isolation. Caplin's theory provides a finely tuned set of tools and examples to scrutinize works, but ultimately the choice between the two lies with the listener's experience with the work in question. It also means that the listener must know the limits of the tools at hand. Problems arise when Caplin's method is viewed not as a theory but as a definitive means of differentiating between transitions and subordinate themes. Instead, I contend that what Caplin so eloquently illustrates are the many ways in which Haydn, Mozart, and Beethoven explored and exploited the expectations of sonata form and its various components, thus making the ambiguous a central compositional attribute, one that may or may not be resolved, rather than insisting upon clear-cut distinctions.

\section{Works Cited}

Caplin, William E. 1998. Classical Form: A Theory of Formal Functions for the Instrumental Music of Haydn, Mozart, and Beethoven. New York: Oxford University Press.

Hepokoski, James, and Warren Darcy. 2006. Elements of Sonata Theory: Norms, Types, and Deformations in the Late-Eighteenth-Century Sonata. New York: Oxford University Press. 


\section{ABSTRACT}

In William Caplin's Classical Form (1998), the ending of a sonata-form exposition's two-part transition and a two-part subordinate theme's internal cadence share the same harmonic goal: the new key's dominant. In this article, the author contends that the choice between the two is not as clear-cut as Caplin suggests, arguing that the functional role of these passages should be read within the context of the entire sonata movement, rather than on more localized analytical interpretations of the sonata's sections taken in isolation. Two works are discussed: the first movement of Beethoven's Piano Sonata op. 2, no. 3, and the first movement of the Piano Sonata op. 10, no. 2.

\section{RÉSUMÉ}

Dans l'ouvrage Classical Form de William Caplin (1998), la conclusion d'une transition en deux parties de l'exposition d'une structure sonate et la cadence interne d'un thème subordonné en deux parties partagent le même objectif harmonique : la dominante de la nouvelle clef. Dans cet article, l'auteur affirme que le choix entre les deux n'est pas aussi net que le suggère Caplin en faisant valoir que la fonction de ces passages doit être lue dans le contexte de la sonate entière, plutôt qu'à travers des interprétations analytiques plus limitées des mouvements de la sonate pris isolément. Deux œuvres de Beethoven sont étudiées : le premier mouvement de la Sonate pour piano, opus 2, $\mathrm{n}^{\mathrm{o}} 3$, et le premier mouvement de la Sonate pour piano, opus 10, $\mathrm{n}^{\circ} 2$. 